\title{
Molecular structures of spider toxins (JSTX-1, 2, 3 and 4) in the venom of Nephila clavata L. Koch
}

\author{
Takashi Toki, ${ }^{1)}$ Tadashi Yasumara, ${ }^{2)}$ Yoshio Aramaki, ${ }^{2)}$ Yuichi Hashimoto, ${ }^{3)}$ \\ Kouichi Shudo, ${ }^{3)}$ Nobufumi Kawai ${ }^{4)}$ and Terumi Nakajima ${ }^{2)}$ \\ 1) Daicel Chemical Industries Ltd., Research Center, Aboshi-ku, Himeji 671-12, Japan \\ 2) Department of Analytical Chemistry and ${ }^{3)}$ Department of Organic Chemistry, \\ Faculty of Pharmaceutical Sciences, The University of Tokyo, \\ Bunkyo-ku, Tokyo 113, Japan \\ s) Department of Neurobiology, Tokyo Metropolitan Institute for Neurosciences, \\ Fuchu, Tokyo 183, Japan
}

(Received: June 14, 1989)

Key words: spider toxin, JSTX, glutamate receptor blocker, Nephila clavata.

\begin{abstract}
Spider toxins in the venom of Nephila clavata L. Koch were investigated and 4 kinds of closely related toxic components, JSTX-1, 2, 3 and 4, were chemically characterized as follows: JSTX-1, 2,4-dihydroxyphenylacetylasparaginyl spermine; JSTX-2, N-(2,4-dihydroxyphenylacetyl-ornithyl-asparaginyl)$\mathrm{N}^{\prime}$-(putreanyl-putreanyl) cadaverine; JSTX-3, N-(2,4-dihydroxyphenylacetyl-asparaginyl) - $\mathrm{N}^{\prime}$-(aminopropyl-putreanyl) cadaverine; JSTX-4, N-(2,4-dihydroxyphenylacetyl-asparaginyl) $-\mathrm{N}^{\prime}$-(arginyl-ornityl) cadaverine. The toxins inhibited glutaminergic neurotransmission in arthropods.
\end{abstract}

\section{INTRODUCTION}

The venom of Nephila clavata L. Koch (Japanese name: Jorogumo) is known as a potent blocker of glutaminergic neurotransmission (Kawai et al., 1982a, b). It is by such action that the spider bites and paralyzes the insects trapped in their webs, since glutamate is the only neurotransmitter at the

1) 土岐 節: ダイセル化学工業 (株)総合研究所

(₹671-12 姫路市網干区新在家 1239)

2)安原 義, 荒牧慶夫, 中䳋暉躬：東京大学薬学部薬 品分析化学教室 (干113 東京都文京区本郷 7-3-1)

3) 㛢本祐一, 首藤紘一：東京大学薬学部薬化学教室 (干113 東京都文京区本郷 7-3-1)

4) 川合述史：東京都神経科学総合研究所（兵183 府中 市武藏台 2-6) neuromuscular junction of the insects. Our earlier communication (Aramaki et al., 1986) reported the isolation of four kinds of toxic components (JSTX-1, 2, 3 and 4) from the venom of the spider. ${ }^{1} \mathrm{H}-\mathrm{NMR}$ studies suggested that these 4 JSTXs were structually similar to each other and all of them possessed 2,4-dihydroxyphenylacetyl moiety linked with polyamines and/or amino acids (Aramaki et al., 1986). One major component, JSTX-3, was characterized chemically to be $\mathrm{N}$-(2,4-dihydroxyphenylacetyl-asparaginyl) - $\mathrm{N}^{\prime}$ - (aminopropyl-putreanyl) cadaverine (Aramaki et al., 1987b). Presently we report the chemical characterization of the other JSTXs. We also discuss the toxicology of the venom of spiders belonging to the genus Nephila. 


\section{Materials and Methods}

Spiders (Nephila clavata) were collected in the outskirts of Tokyo. Venom glands of the spiders were removed and kept in a deep freezer until use. A typical purification procedure of the toxin is given below. Twelve glands were homogenized in $1,000 \mu \mathrm{l}$ of $0.1 \%$ trifluoroacetic acid and centrifuged at 12,000 $\mathrm{rpm}$ for $5 \mathrm{~min}$. The supernatant fluid was passed through a TOYOPAK-ODS cartridge (TOSOH Ltd.) pre-equilibrated with $0.1 \%$ trifluoroacetic acid, and the adsorbed material was eluted with $30 \%$ acetonitrile containing $0.1 \%$ trifluoroacetic acid. Both non-adsorbed and adsorbed fractions were evaporated under reduced pressure and the residues were chromatographed on a reversed phase ODS column as described previously (Toki et al., 1988a). The HPLG fractions corresponding to four peaks monitored at $220 \mathrm{~nm}$ were collected separately. The biological activities of purified toxins were assayed for inhibitory effect on the excitatory postsynaptic potentials using a neuromuscular junction of lobster's walking leg (Kawai et al., 1982a). Analytical methods and procedures employed in this experiment were as follows: Amino acids and polyamines obtained by complete hydrolysis of the toxins were determined by amino acid and polyamine analyzer with orthophthalaldehyde method as described by Nakajima et al. (1983). Sequential analysis of the polycationic part of the toxins were carried out by a combination of $\mathrm{N}$-terminal analysis with dansyl method and fragmentation of toxins by partial acid hydrolysis (Toki et al., $1988 \mathrm{a}, \mathrm{b})$. In essence, the intact toxin was first dansylated and secondarily hydrolyzed by the usual manner with $5.7 \mathrm{~N} \mathrm{HCl}$ at $110^{\circ} \mathrm{C}$ for $20 \mathrm{hr}$. The dansylated amino acid or polyamines were identified by reversed phase HPLC using authentic samples as standards. Partial hydrolyzate with $5.7 \mathrm{~N}$ $\mathrm{HCl}$ at $100^{\circ} \mathrm{C}$ for $20 \mathrm{~min}$ was treated in a similar manner and the composition of the amino acids and polyamines of each fragment was determined. To distinguish between aspartic acid and asparagine in each sequence, the native toxin was first treated with bis-(1,1-trifluoroacetoxy) iodobenzene which converted asparagine to $\alpha, \beta$-diaminopropionic acid (Soby and Johnson, 1981). Confirmation of the presence of 2,4-dihydroxyphenylacetyl group was done by HPLC analysis of the hydrolyzed component. After hydrolysis of JSTXs with $0.025 \mathrm{M}$ oxalic acid at $100^{\circ} \mathrm{C}$ for $16 \mathrm{hr}$, the hydrolyzate was injected on the reversed phase HPLC system (Aramaki et al., 1987a). The substituent component was identified by the elution time and the UV spectrum monitored by a photodiode-array detector.

\section{Results}

The chromatogram of the venom gland extracts is shown in Fig. 1a. To isolate toxic substances efficiently, the venom gland extracts were first passed through a TOYOPAK-ODS cartridge. Since the fraction eluted within $38 \mathrm{~min}$ in Fig. 1a, which contained JSTX-1, was not adsorbed on the cartridge, JSTX-1 was purified by rechromatography of the non-adsorbed fraction. This toxin was exactly the same as the one we synthesized in the course of our investigations on the structure-activity relationship of analogous compounds (Hashimoto et al., 1987). The toxin was composed of 2,4-dihydroxyphenylacetic acid, asparagine and spermine. Spermine was linked at the terminus of the molecule, since $\mathrm{N}^{1}, \mathrm{~N}^{5}, \mathrm{~N}^{10}$ tridansyl spermine was detected from the hydrolyzate of the dansylated JSTX-1. Other toxins (JSTX-2, 3 and 4) were isolated from the adsorbed fraction. The chromatogram of the adsorbed fraction is shown in Fig. 1b.

JSTX-3 was eluted at $10.6 \mathrm{~min}$ (Fig. 1b), which was confirmed by cochromatography with authentic JSTX-3. JSTX-2 and 4 eluted as adjacent peaks at 11.0 and 11.2 min, respectively. The large peaks eluted around $13 \mathrm{~min}$ (Fig. 1b) were a mixture of Nephilatoxins (NPTXs) (Toki et al., 1988a, b) which not only inhibited the glutamate receptor, but also released histamine from the mast cells. The fractions containing JSTX-2 and 4 were rechromatographed with the flatter gradient system, and the components in each fraction were isolated. JSTX-2 contained $1 \mathrm{~mol}$ of asparagine, cadaverine ornithine and $2 \mathrm{~mol}$ of putreanine in addition to 2,4-dihydroxyphenylacetic acid. This 


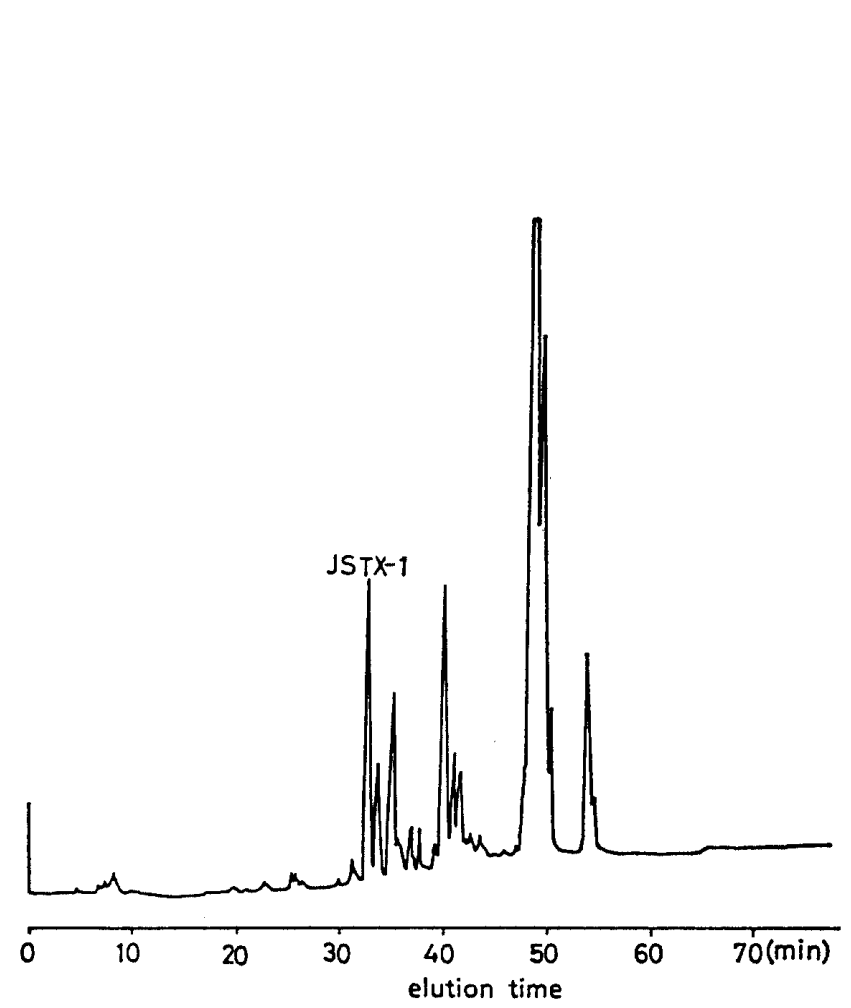

(a)

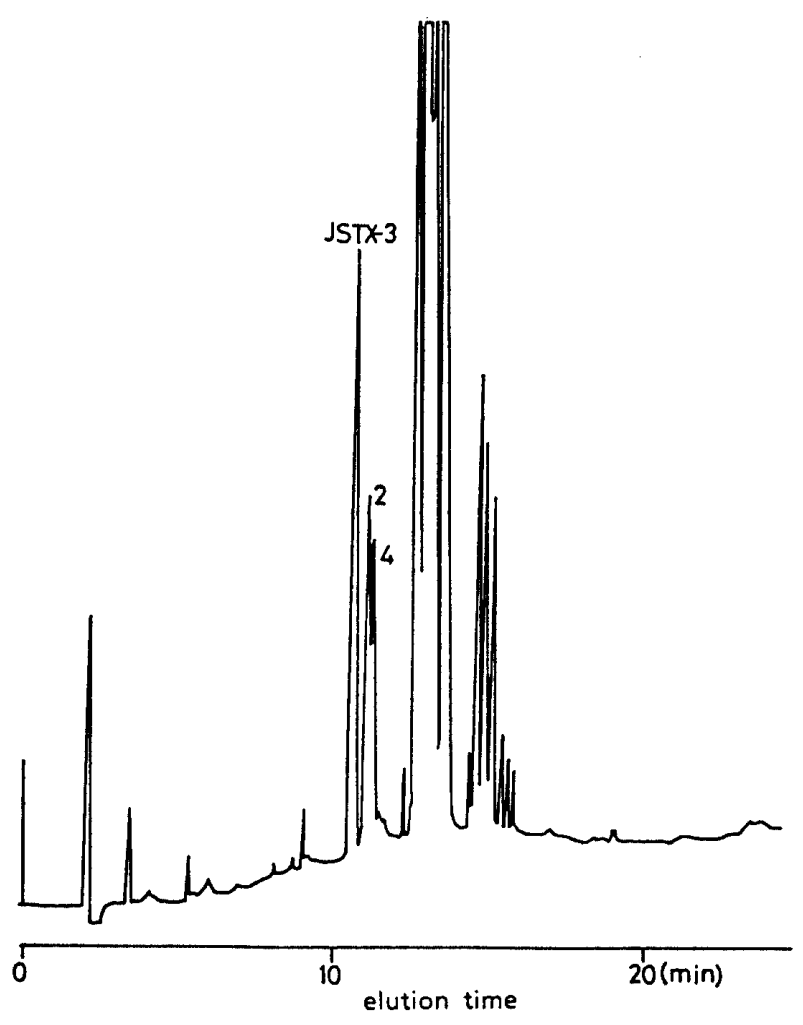

(b)

Fig. 1a Chromatogram of venom gland extracts of Nephila clavata. Column, TSK-gel ODS-120T, $0.46 \times 250 \mathrm{~mm}$ (left).

Eluent, linear gradient from $0.1 \%$ trifluoroacetic acid to $30 \%$ acetonitrile containing $0.1 \%$ trifluoroacetic acid. Elution in $60 \mathrm{~min}$ at a flow rate of $0.7 \mathrm{ml} / \mathrm{min}$. Column temperature, $25^{\circ} \mathrm{C}$. Detection, UV $280 \mathrm{~nm}$.

Fig. 1b Chromatogram of the fraction adsorbed on ODS-cartridge.

Coíumn, TSK-gel ODS-80TM, $0.46 \times 250 \mathrm{~mm}$. Eluent, linear gradient from $0.1 \%$ trifluoroacetic acid to $30 \%$ acetonitrile containing $0.1 \%$ trifluoroacetic acid. Elution in $30 \mathrm{~min}$ at a flow rate of $1.0 \mathrm{ml} / \mathrm{min}$. Column temperature, $50^{\circ} \mathrm{C}$. Detection, UV $220 \mathrm{~nm}$ (right).

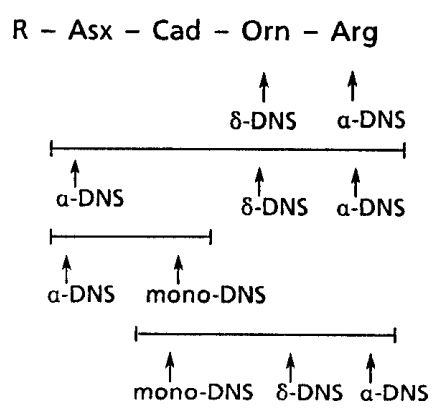

Fig. 2 Sequence analysis of JSTX-4.

amine component was the same as that of NPTX-3 (Toki et al., 1988a). The amino acid and polyamine component of JSTX-4 was $1 \mathrm{~mol}$ of asparagine, cadaverine ornithine and arginine which is also the same as that of NPTX-9 (Toki et al., 1988a). Sequence analysis of the polyamine part of these two toxins gave the same results as those of NPTX-3 and 9, respectively. As an example, sequence analysis of JSTX-4 is summarized in Fig. 2.

Accordingly, the structure of JSTX-2 and 4 were deduced to be $\mathrm{N}$-(2,4-dihydroxyphenylacetyl - ornithyl - asparaginyl) $\mathrm{N}^{\prime}$ - (putreanyl-putreanyl) cadaverine and $\mathrm{N}$ (2, 4-dihydroxyphenylacetyl-asparaginyl) - $\mathrm{N}^{\prime}$ (arginylornithyl) cadaverine, respectively. Structures of JSTXs and the related polyamine-like toxins isolated from spider venom are illustrated in Figs. 3a and 3b.

\section{Discussion}

The venom of Nephila clavata was observed electrophysiologically to block irreversibly the neuromuscular junction of the 
JSTX-1

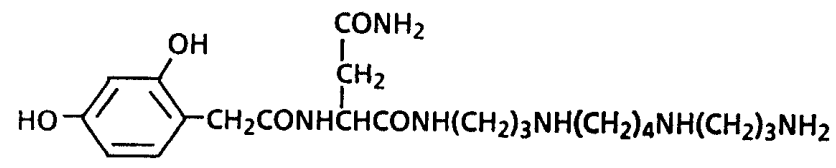

JSTX-2

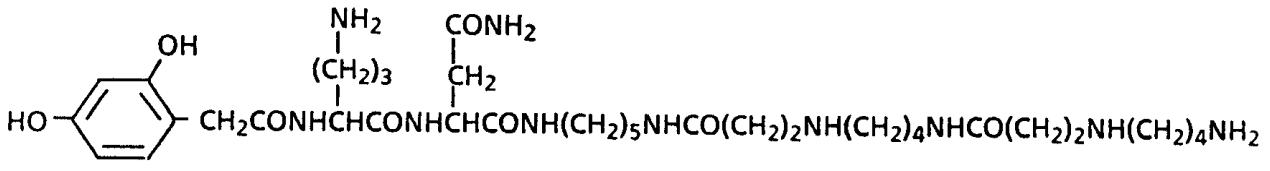

JSTX-3 (Aramaki et al., 1986)

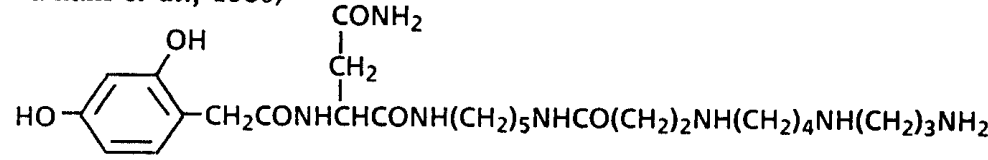

JSTX-4

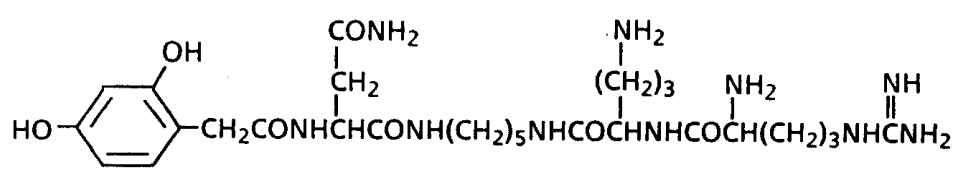

Fig. 3a Chemical structures of JSTXs.

NPTX-3 ('Toki et al., 1988b)

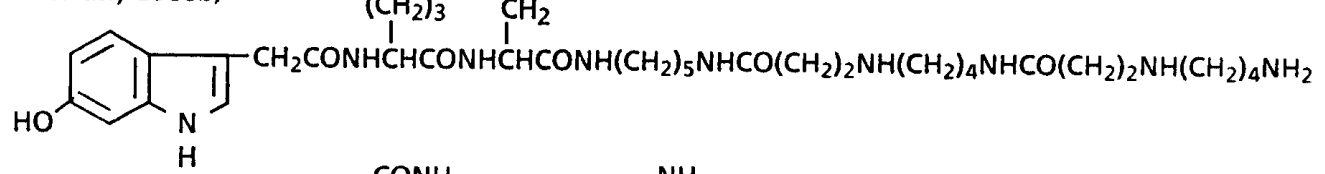
$\mathrm{H}$

NPTX-9 (Toki et al., 1988a)

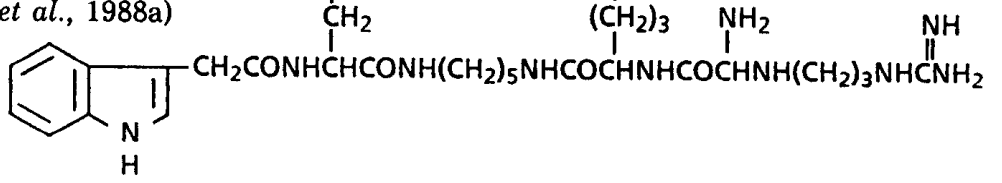

Argiotoxin 673 (Adams et al., 1987)

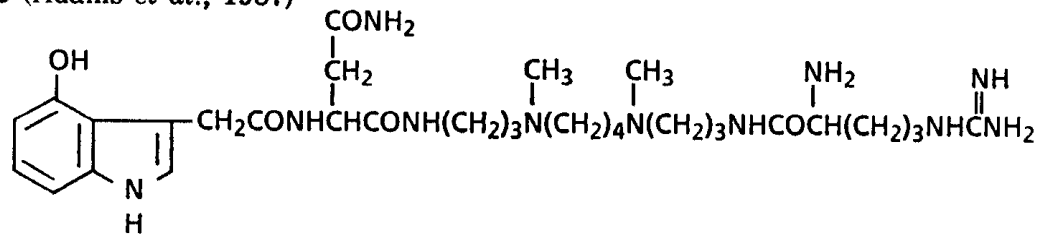

Argiopine (Grishin et al., 1986)

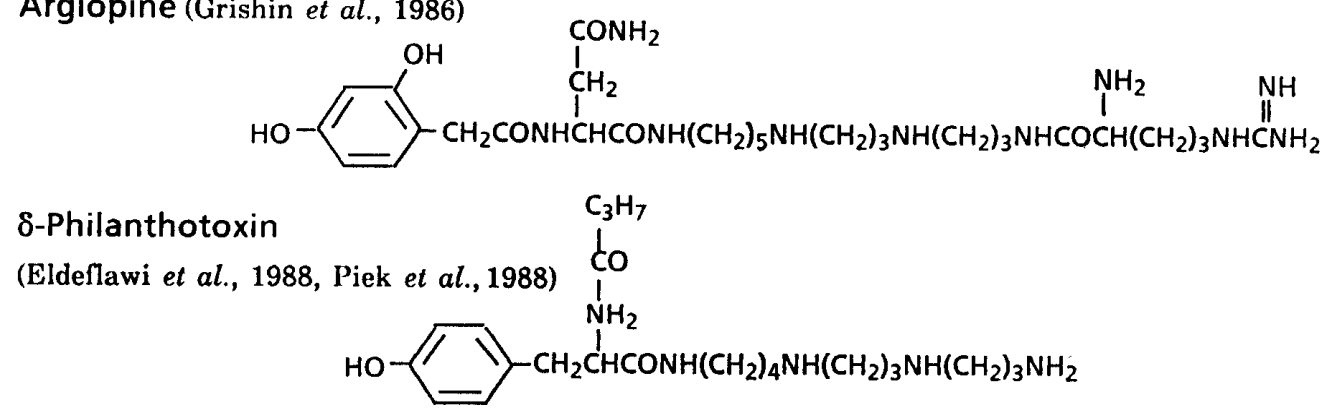

Fig. $3 b$ Structures of polyamine conjugated toxins.

walking leg of lobster (Kawai et al., 1982a). They also noted that the venom was a potent blocker against quisqualate type glutamate receptor in mammalian brain (Kawai et al., 1982b). They called the toxin in the venom, "Joro spider toxin (JSTX)." Chemical characterization of the venom leads us to the conclusion that JSTX was a mixture of 
more than 16 kinds of closely related compounds. These toxins are named JSTX-1 to 4 and NPTX-1 to 12 (Aramaki et al., 1986, 1987a, b; Toki et al., 1988a, b). During the past few years, the toxins in the araneid spiders belonging to the genera, Araneus, Argiope, Neoscone, and Nephila have been characterized (Aramaki et al., 1986; Grishin et al., 1986, 1988; Adames et al., 1987; Toki et al., 1988b; etc.). Chemical structures of these toxins are similar to each other as shown in Fig. 3b, and their physiological action is practically the same with respect to the blocking action of the glutamate receptor. In this regard, the toxins in the araneid spiders may be classified as a new type of polyamine toxins. However there exists minor structural differences among them. Most of the toxins in Nephila possessing putreanine (carboxyethyl putrescine) which is linked directly with cadaveryl asparagine in the molecule. While putreanine has not been found as a component of toxins from the venom of the other genera, the toxins in the other genera contain longer chain polyamines instead of putreanine or $\mathrm{N}$-methylated polyamines and/or $\mathrm{N}$-methylated amino acids. However, this type of polyamine conjugated toxin may be characteristic in the venom of the spiders in the family, Araneidae, since in the chromatographic pattern analysis of the spider venom belonging to other families, such as Loxoscelidae, Agelenidae, Clubionidae, etc., we could not find this type of polyamine conjugated toxins (Hagiwara et al., unpublished). On the other hand, some kinds of solitary wasps belonging to the genera, Pompilus, Eumenes, Sphex, etc., are known to contain similarly acting neurotoxins which cause paralysis in insects, and the wasps lay their eggs on prays anesthetized in this manner. $\delta$ Philanthotoxin in the venom of a sphecid wasp, Philanthus triangulum, is the best investigated (Clark et al., 1982; Eldeflawi et al., 1988; Piek et al., 1988) and, interestingly, the chemical structure of the toxic principle is also a polyamine conjugated toxin, ( $n$-butyryl-tyrosyl)-1,12-diamino-5,9diazadodecane. The above results suggest the use of a new class of polyamine-like toxins for the development of new pesticides and for the study of glutaminergic transmission.

\section{REFERENCES}

Adames, M. E., R. L. Carney, F. E. Enderlin, E. T. Fu, M. A. Jamrema, J. P. Li, C. A. Miller, D. A. Schooley, M. J. Shapiro and V. J. Venema (1987): Structure and biological activities of three synaptic antagonists from orb weaver spider venom. Biochem. Biophys. Res. Commun., 148: 678-683.

Aramaki, Y., T. Yasuhara, T. Higashijima, A. Miwa, N. Kawai and T. Nakajima (1987a): Chemical characterization of spider toxin, NSTX. Biomed. Res., 8: 167-173.

Aramaki, Y., T. Yasuhara, T. Higashijima, T. Yoshioka, A. Miwa, N. Kawai and T. Nakajima (1986): Chemical characterization of spider toxin, JSTX and NSTX. Proc. Jpn., Acad. Ser. B, 62: 359-362.

Aramaki, Y., T. Yasuhara, K. Shimazaki, N. Kawai and T. Nakajima (1987b): Chemical characterization of Joro spider toxin (JSTX). Biomed. Res., 8: 241-245.

Clark, R. B., P. L. Donaldson, K. A. F. Gration, J. J. Lambert, T. Piek, R. Ramsey, W. Spajer and P. N. R. Usherwood (1982): Block of locust muscle glutamate receptors by deltaPhilanthotoxin occurs after receptor activations. Brain Res., 241 : 105-114.

EIdeflawi, A. T., M. E. Eldeflawi, K. Konno, N. A. Mansour, K. Nakanishi, E. Oltz and P. N. R. Usherwood (1988): Structure and synthesis of a potent glutaminergic receptor antagonist in the wasp venom. Proc. Natl. Acad. Sci., 85: 4910-4913.

Grishin, E. M., T. M. Volkova and A. S. Arseniev (1988): Antagonists of glutamate receptors from the venom of Argiope lobata spider. Bioorg. Khim., 7: 883-892.

Grishin, E. M., T. M. Volkova and A. S. Arseniev, O. S. Reshetova, V. V. Onoprienko, L. G. Magazanic, S. M. Antonov and I. M. Federova (1986) : Structure-functional characterization of argiopine an ionchannel blocker from the venom of spider, Argiope lobata. Bioorg. Khim., 12: 1121-1124.

Hashimoto, Y., Y. Endou, K. Shudo, Y. Aramaki, N. Kawai and T. Nakajima (1987): Synthesis of spider toxin (JSTX-3) and its analogs. Tetrahedron Lett., 28: 3511-3514.

Kawai, N., A. Miwa and T. Abe (1982a): Spider venom contains specific receptor blocker of glutaminergic synapses. Brain Res., 247: 169-171.

Kawai, N., A. Miwa and T. Abe (1982b) : Effect of spider toxin on glutaminergic synapses in the mammalian brain. Biomed. Res., 3: 353355.

Nakajima, T., T. Yasuhara, N. Yoshida, Y. Take- 
moto, S. Shinonaga, R. Kano and H. Yoshida (1983): The pattern analysis of biologically active amines in some Hymenopteran venoms by high performance liquid chromatography. Jpn. J. Sanit. Zool., 34: 61-71.

Piek, T., R. H. Fokkens, H. Karst, C. Kruk, A. Lind, J. van Marle, T. Nakajima, N. M. M. Nibbering, H. Shinozaki and W. Spanjar (1988): Polyamine-like toxins-A new class of pesticedes? In Neurotox. '88, Molecular Basis of Drugs and Pesticides Action (ed. Lunt, G. G.), pp. 61-76, Excerptamedica, Amsterdam, New York, Oxford.

Soby, L. M. and P. Johnson (1981): Determination of asparagine, glutamine in polypeptide using bis(1,1-trifluoroacetoxy) iodobenzene. Anal. Biochem., 113: 149-153.

Toki, T., T. Yasuhara, Y. Aramaki, N. Kawai and T. Nakajima (1988a): A new type of spider toxin, Nephilatoxin, in the venom of Joro spider, Nephila clavata. Biomed. Res., 9: 75-79.
Toki, T., T. Yasuhara, Y. Aramaki, K. Osawa, A. Miwa, N. Kawai and T. Nakajima (1988b) : Isolation and chemical characterization of a series of spider toxin (Nephilatoxins) in the venom of Joro spider, Nephila clavata. Biomed. Res., 9: 421-428.

\section{摘要}

日本産ジョロウグモ Nephila clavata の 毒成分（JSTX-1,2,3,4）について

日本産ジョロウグモ Nephila clavata の毒注，グ ルタミン酸レセプターの遮断剂として知られている. 今回ジョロウグモ毒中に存在する 4 種類の毒成分, JSTX-1，2，3，および 4 について構造解析を行った. これらの毒成分はスペルミンまたはカダベリンの両端 に塩基性アミノ酸あるいはポリアミンが結合し，置換 基として 2,4-ジヒドロキシフェニルアセチル基をもつ 特異な構造を有していた. また単離した毒成分はいず れもグルタミン酸レセプター遮断活性を示した。 